Pak. j. sci. ind. res. Ser. A: phys. sci. 201558 (2) 106-110

\title{
Amenability of Carboxylic Acids Adsorption on Surface of Activated Carbon
}

\author{
Tayyba Aftab, Naeem Abbas*, Muhammad Irfan, Farah Deeba, \\ Naz Imtiaz and Rauf Ahmad Khan \\ Centre for Environment Protection Studies, PCSIR Laboratories Complex, Ferozepur Road, \\ Lahore - 54600, Pakistan
}

(receivd December 11, 2013; revised July 11, 2014; accepted July 18, 2014)

\begin{abstract}
The objective of the present study was to investigate the adsorption of benzoic acid (BA), valeric acid (VA), propionic acid (PA) and butyric acid (BUA) from aqueous solutions at different dosing rate on the surface of activated carbon. Different trials were taken in order to determine the interaction between the carbon surface and adsorbent species. The residual concentration of acids was calculated by the titrimetric method. Maximum adsorption capacity was found to be $93.37 \%$ at dosing rate of $8.75 \mathrm{~g}$ for BUA and minimum adsorption capacity was measured as $41.47 \%$ at dosing rate of $0.69 \mathrm{~g}$ for VA. Keeping the same contact time and mass of activated carbon $(2.8 \mathrm{~g})$, the adsorption capacity increases with increasing dosing rate.
\end{abstract}

Keywords: activated carbon, benzoic acid, titrimetric method, adsorption capacity, dose rate

\section{Introduction}

Carboxylic acids are used in various industries for the production of polymers, pharmaceuticals, solvents, and food additives. Propionic acid is an important member of carboxylic acid family: used as intermediate for the production of other chemicals, a preservative for both animal feed and food for human consumption, especially polymers and artificial flavourings (Bertleff et al., 2005). Butyric acid is widely used as an animal feed supplement due to its ability to reduce pathogenic bacterial colonisation. Butyric acid has a powerful odour. It has also been used as a fishing bait additive. Valeric acid has been widely used in perfumes and cosmetics industries due to its pleasant odour.

Benzoic acid (BA) is one of the most important additives in the food industry. Many countries such as China, Japan, and the European Union have banned the usage of BA as a food additive due to its toxic nature. BA is also used in the formation of many compounds and produced exclusively by the liquid phase oxidation of toluene. It can be detected in industrial sewage, which could affect the human health (Xin et al., 2011). Therefore, the removal of carboxylic acid in water brings much public attention (Dong et al., 2006). Adsorption behaviour of acidic compounds with different adsorbents like activated carbons, montmorillonites, mesoporous silicas, soils and bentonites has been investigated by many earlier researchers (Yan et al., 2007; Ayranci and Duman, 2006).

*Author for correspondence; E-mail: naeemchemist@gmail.com
Activated carbon is one of the oldest and the most widely used adsorbents for the adsorption of organic compounds. It has been utilised in powder or granular form. These forms have been the primary adsorbent materials for many adsorption studies on organic compounds (Ania et al., 2002; Abe et al., 2000). Many studies have reported the adsorption of acid on surface of activated carbon (Dina et al., 2012). The adsorption behaviour of activated carbon from adsorbate solutions is affected by both the surface and the solution properties (Haghseresht et al., 2002). Presence of surface functional groups such as carboxyl, lactone, phenol, carbonyl, ether, pyrone and chromene gives activated carbon an acidbase character (Rodriguez-Reinoso and Molina-Sabio, 1998). Surface charge density is also an important factor in determining the adsorption characteristics of activated carbon.

Various surface structures and chemistry are expected to play a role during the adsorption process. Carboxylic acids are used in various industries for the production of various types of compounds; hence, these are present in wastewater generated in these industries. Thus, it is important to remove these compounds by a suitable and economic process before discharge of these wastewaters. The objective of the present study was to investigate the adsorption behaviours by use of activated carbon (AC) for the removal of benzoic acid (BA), valeric acid (VA), butyric acid (BUA) and propionic acid (PA) from aqueous solutions by changing their initial concentration. 
The performance of activated carbon is evaluated by using different dosing rate of carboxylic acids.

\section{Materials and Methods}

Benzoic acid, valeric acid, butyric acid and propionic acid were obtained from Merck, whereas phenolphthalein and sodium hydroxide were reagent grade. Activated carbon was applied in powdered form in batch experiment which had been purchased from BDH chemicals. The characteristic of activated carbon before experiment was summarized in Table 1.

Table 1. Characteristics of activated carbon

\begin{tabular}{ll}
\hline \hline Parameters & Results \\
\hline $\mathrm{pH}$ & $6.8 \pm 0.05$ \\
Moisture content $(\%)$ & $11 \pm 0.10$ \\
Bulk density $\left(\mathrm{g} / \mathrm{cm}^{3}\right)$ & $0.317 \pm 0.02$ \\
Tap density $\left(\mathrm{g} / \mathrm{cm}^{3}\right)$ & $0.672 \pm 0.04$ \\
Surface area $(\mathrm{BET})\left(\mathrm{m}^{2} / \mathrm{g}\right)$ & $980 \pm 1.45$ \\
Pore volume $\left(\mathrm{g} / \mathrm{cm}^{3}\right)$ & $1.43 \pm 0.05$ \\
Porosity $(\%)$ & $75.74 \pm 1.05$ \\
Particle size $(\mathrm{mm})$ & $3.7 \pm 0.02$ \\
\hline \hline
\end{tabular}

Batch equilibrium experiments. All experiments were carried out in a reagent bottle with same amount of carbon $(2.8 \mathrm{~g})$ added in it. The carboxylic acids used were propionic, butyric, valeric and benzoic acids. The stock solution of each acid was prepared (i.e., 4, 16, 24, 40, $50,70,80$ and $100 \%$ ) by keeping its volume $50 \mathrm{~mL}$ with double distilled water. For adsorption of acids on activated carbon, same amount of carbon was $(2.8 \mathrm{~g})$ added in each bottle and placed for $30-45 \mathrm{~min}$ at $30{ }^{\circ} \mathrm{C}$ in a shake machine to reach $95 \%$ equilibrium. Then the solution was filtered off over a measuring cylinder. After discarding the first $5 \mathrm{~mL}$ of the filtrate, $25 \mathrm{~mL}$ was taken in Erlenmeyer flask for titration. Phenolphthalein (4 drops) was added and titrated with standard sodium hydroxide solution.

The adsorbed quantities of acid, X, were obtained by subtracting the residual concentration at equilibrium $\alpha_{e}$, from the initial concentration, $\alpha_{0}$ Thus,

$$
X=\alpha_{0}-\alpha_{e}
$$

and $Q_{e}$ the quantity of carboxylic acid adsorbed (adsorption capacity) per gram of adsorbent of mass $\mathrm{m}$, $\mathrm{V}$ is volume. It can be expressed as:

$$
\mathrm{Q}_{\mathrm{e}}=\frac{\alpha_{\mathrm{o}}-\alpha_{\mathrm{e}}}{\alpha_{\mathrm{o}}} \mathrm{V}
$$

\section{Results and Discussion}

Adsorption of benzoic acid (BA). Results reveal that by increasing dosing rate, the adsorption of acid on activated carbon also increases. The concentration of acids provides necessary driving force to overcome the resistance to the mass transfer of adsorbate between aqueous and the solid phases. Moreover, the increase of concentration enhances the interaction between adsorbate and the adsorbent. Table 2 shows that keeping constant mass of carbon as $2.8 \mathrm{~g}$ and increasing dosing rate of benzoic acid from $0.09 \mathrm{~g}$ to $2.60 \mathrm{~g}$, adsorption capacity of carbon increases from $2.22 \%$ to $91.30 \%$. From Fig. 1 it is clear that the adsorption capacity was increased gradually up to dosing rate of $1.83 \mathrm{~g}$ then increased sharply at dosing rate of $2.6 \mathrm{~g}$ and became linear after it. The value of $\mathrm{X} / \mathrm{m}$ and $\mathrm{C}_{\mathrm{eq}}$ also increased gradually by increasing concentration of BA.

Table 2. Adsorption of benzoic acid on activated carbon

\begin{tabular}{lllllllllll}
\hline \hline $\begin{array}{l}\text { S. } \\
\text { no. }\end{array}$ & $\begin{array}{l}\mathrm{m} \\
(\mathrm{g})\end{array}$ & $\begin{array}{l}\text { Dilution } \\
(\%)\end{array}$ & $\begin{array}{l}\alpha_{\mathrm{o}} \\
(\mathrm{g})\end{array}$ & $\begin{array}{l}\mathrm{NaOH} \\
(\mathrm{mL})\end{array}$ & $\begin{array}{l}\mathrm{C}_{\mathrm{e}} \\
(\mathrm{mole} / \mathrm{L})\end{array}$ & $\begin{array}{l}\alpha_{\mathrm{e}} \\
(\mathrm{g})\end{array}$ & $\begin{array}{l}\mathrm{X}=\alpha_{\mathrm{o}}-\alpha_{\mathrm{e}} \\
(\mathrm{g})\end{array}$ & $\begin{array}{l}\mathrm{X} / \mathrm{m} \\
(\mathrm{g})\end{array}$ & $\begin{array}{l}\mathrm{C}_{\mathrm{eq}} \\
(\mathrm{g})\end{array}$ & $\begin{array}{l}\mathrm{Q}_{\mathrm{e}} \\
\mathrm{mg} / \mathrm{g}\end{array}$ \\
\hline 1. & 2.8 & 4 & 0.09 & 0.06 & 0.003 & 0.002 & 0.088 & 0.032 & 0.0094 & 2.22 \\
2. & 2.8 & 16 & 0.42 & 1.19 & 0.010 & 0.038 & 0.383 & 0.136 & 0.0735 & 9.00 \\
3. & 2.8 & 24 & 0.71 & 2.45 & 0.015 & 0.089 & 0.621 & 0.222 & 0.0675 & 12.35 \\
4. & 2.8 & 40 & 0.93 & 6.43 & 0.032 & 0.173 & 0.757 & 0.270 & 0.1185 & 18.60 \\
5. & 2.8 & 50 & 1.41 & 8.15 & 0.046 & 0.222 & 1.188 & 0.424 & 0.1084 & 26.66 \\
6. & 2.8 & 70 & 1.62 & 9.52 & 0.081 & 0.400 & 1.221 & 0.436 & 0.1857 & 24.62 \\
7. & 2.8 & 80 & 1.83 & 10.62 & 0.112 & 0.570 & 1.260 & 0.450 & 0.2488 & 31.14 \\
8. & 2.8 & 100 & 2.60 & 11.94 & 0.241 & 1.91 & 0.69 & 0.226 & 1.0663 & 91.30 \\
\hline \hline
\end{tabular}

$\mathrm{m}=$ weight of activated carbon $(\mathrm{g}) ; \alpha_{\mathrm{o}}=$ amount of carboxylic acid added to the bottle $(\mathrm{g}) ; \mathrm{C}_{\mathrm{e}}=$ concentration of carboxylic acid left in solution at equilibrium (mole/L); $\alpha_{\mathrm{e}}=$ amount of carboxylic acid left in solution at equilibrium in the bottle (g); $\mathrm{X}=$ amount of carboxylic acid adsorbed $(\mathrm{g}) ; \mathrm{Q}_{\mathrm{e}}=$ adsorption capacity of acids (mg/g). 


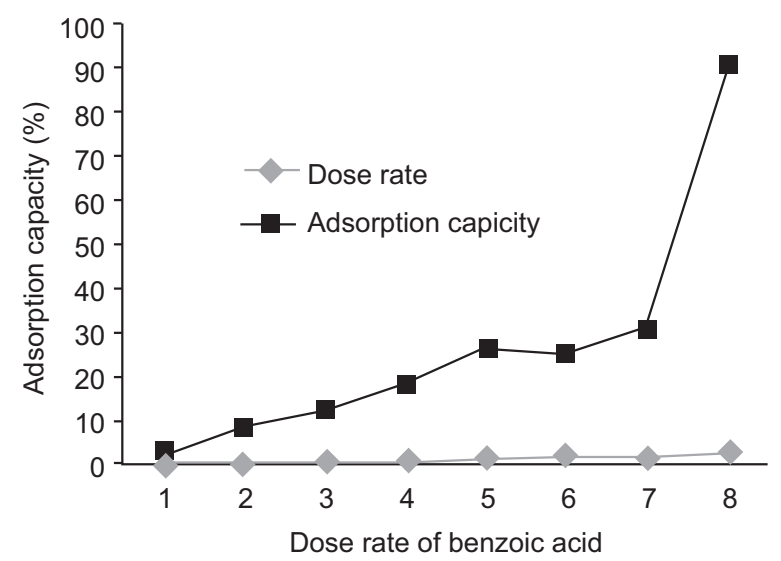

Fig. 1. Effect of dose rate on adsorption capacity of benzoic acid.

Adsorption of propionic acid (PA). Adsorption of propionic acid from the aqueous solution on the surface of activated carbon was increased by increasing dosing rate as shown in Fig. 2. The adsorption capacity was increased from $1.69 \%$ up to $65.28 \%$ by increasing dosing rate of propanoic acid from $0.059 \mathrm{~g}$ up to $1.472 \mathrm{~g}$. The value of $\mathrm{X} / \mathrm{m}$ ranging from 0.021 to 0.148 and $\mathrm{C}_{\mathrm{eq}}$ values from 0.018 to 1.411 are presented in Table 3 .

Adsorption of valeric (VA) and butyric acid (BUA). The adsorption of valeric acid molecule with linear structure has more surface area as compared to its branched structure. More fatty acid get adsorbed with chain parallel to surface due to high affinity (Kipling, 1965).

The adsorption capacity of valeric acid increased sharply up to dosing rate of $0.692 \mathrm{~g}$ from $0.082 \mathrm{~g}$ as shown in Fig. 3. The value of $\mathrm{X} / \mathrm{m}$ ranges from 0.029 to 0.446 and $\mathrm{C}_{\mathrm{eq}}$ values from 0.007 to 0.313 . Adsorption capacity was decreased at $0.820 \mathrm{~g}$ and then increased gradually

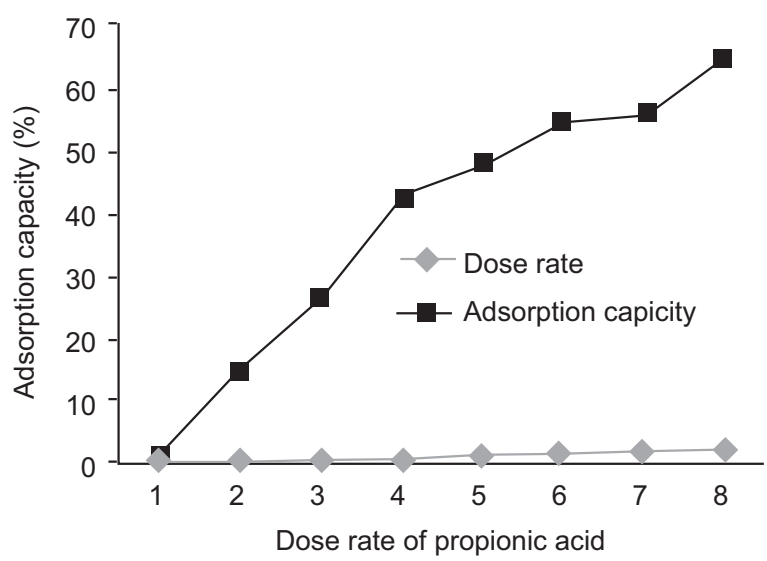

Fig. 2. Effect of dose rate on adsorption capacity of propionic acid.

up to $2.05 \mathrm{~g}$ as shown in Table 4. With butyric acid, adsorption capacity was sharply increased up to $93.37 \%$ with dosing rate of $8.75 \mathrm{~g}$ then became linear after it

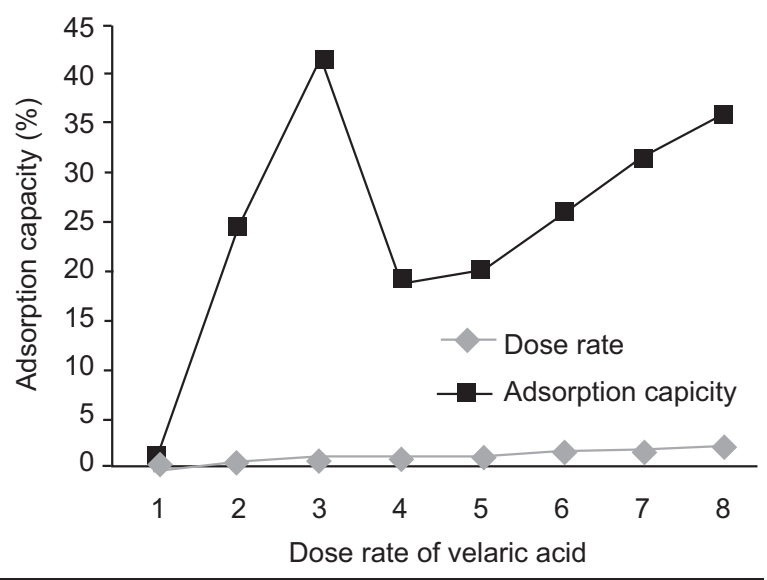

Fig. 3. Effect of dose rate on adsorption capacity of valeric acid.

Table 3. Adsorption of propionic acid on activated carbon

\begin{tabular}{lllllllllll}
\hline \hline $\begin{array}{l}\text { S. } \\
\text { no. }\end{array}$ & $\begin{array}{l}\mathrm{m} \\
(\mathrm{g})\end{array}$ & $\begin{array}{l}\text { Dilution } \\
(\%)\end{array}$ & $\begin{array}{l}\alpha_{\mathrm{o}} \\
(\mathrm{g})\end{array}$ & $\begin{array}{l}\mathrm{NaOH} \\
(\mathrm{mL})\end{array}$ & $\begin{array}{l}\mathrm{C}_{\mathrm{e}} \\
(\mathrm{mole} / \mathrm{L})\end{array}$ & $\begin{array}{l}\alpha_{\mathrm{e}} \\
(\mathrm{g})\end{array}$ & $\begin{array}{l}\mathrm{X}=\alpha_{\mathrm{o}}-\alpha_{\mathrm{e}} \\
(\mathrm{g})\end{array}$ & $\begin{array}{l}\mathrm{X} / \mathrm{m} \\
(\mathrm{g})\end{array}$ & $\begin{array}{l}\mathrm{C}_{\mathrm{eq}} \\
(\mathrm{g})\end{array}$ & $\begin{array}{l}\mathrm{Q}_{\mathrm{e}} \\
\mathrm{mg} / \mathrm{g}\end{array}$ \\
\hline 1. & 2.8 & 4 & 0.059 & 0.10 & 0.0003 & 0.0015 & 0.058 & 0.021 & 0.018 & 1.69 \\
2. & 2.8 & 16 & 0.236 & 2.40 & 0.0095 & 0.035 & 0.201 & 0.068 & 0.140 & 14.83 \\
3. & 2.8 & 24 & 0.354 & 6.40 & 0.094 & 0.094 & 0.260 & 0.099 & 0.256 & 26.55 \\
4. & 2.8 & 40 & 0.589 & 15.70 & 0.230 & 0.230 & 0.339 & 0.129 & 0.482 & 42.95 \\
5. & 2.8 & 50 & 0.736 & 24.0 & 0.352 & 0.352 & 0.334 & 0.145 & 0.652 & 47.82 \\
6. & 2.8 & 70 & 1.031 & 39.0 & 0.572 & 0.572 & 0.459 & 0.172 & 0.900 & 54.51 \\
7. & 2.8 & 80 & 1.178 & 45.0 & 0.660 & 0.660 & 0.518 & 0.173 & 1.031 & 56.02 \\
8. & 2.8 & 100 & 1.472 & 65.5 & 0.961 & 0.961 & 0.511 & 0.184 & 1.411 & 65.28 \\
\hline
\end{tabular}

$\mathrm{m}=$ weight of activated carbon $(\mathrm{g}) ; \alpha_{\mathrm{o}}=$ amount of carboxylic acid added to the bottle $(\mathrm{g}) ; \mathrm{C}_{\mathrm{e}}=$ concentration of carboxylic acid left in solution at equilibrium (mole/L); $\alpha_{\mathrm{e}}=$ amount of carboxylic acid left in solution at equilibrium in the bottle $(\mathrm{g})$; $\mathrm{X}=$ amount of carboxylic acid adsorbed $(\mathrm{g}) ; \mathrm{Q}_{\mathrm{e}}=$ adsorption capacity of acids $(\mathrm{mg} / \mathrm{g})$. 
Table 4. Adsorption of valeric acid on activated carbon

\begin{tabular}{lllllllllll}
\hline \hline $\begin{array}{l}\text { S. } \\
\text { no. }\end{array}$ & $\begin{array}{l}\mathrm{m} \\
(\mathrm{g})\end{array}$ & $\begin{array}{l}\text { Dilution } \\
(\%)\end{array}$ & $\begin{array}{l}\alpha_{\mathrm{o}} \\
(\mathrm{g})\end{array}$ & $\begin{array}{l}\mathrm{NaOH} \\
(\mathrm{mL})\end{array}$ & $\begin{array}{l}\mathrm{C}_{\mathrm{e}} \\
(\mathrm{mole} / \mathrm{L})\end{array}$ & $\begin{array}{l}\alpha_{\mathrm{e}} \\
(\mathrm{g})\end{array}$ & $\begin{array}{l}\mathrm{X}=\alpha_{\mathrm{o}}-\alpha_{\mathrm{e}} \\
(\mathrm{g})\end{array}$ & $\begin{array}{l}\mathrm{X} / \mathrm{m} \\
(\mathrm{g})\end{array}$ & $\begin{array}{l}\mathrm{C}_{\mathrm{eq}} \\
(\mathrm{g})\end{array}$ & $\begin{array}{l}\mathrm{Q}_{\mathrm{e}} \\
\mathrm{mg} / \mathrm{g}\end{array}$ \\
\hline 1. & 2.8 & 4 & 0.082 & 0.05 & 0.0002 & 0.001 & 0.081 & 0.029 & 0.007 & 1.22 \\
2. & 2.8 & 16 & 0.382 & 2.05 & 0.008 & 0.041 & 0.287 & 0.102 & 0.078 & 24.86 \\
3. & 2.8 & 24 & 0.692 & 4.35 & 0.017 & 0.087 & 0.405 & 0.143 & 0.119 & 41.47 \\
4. & 2.8 & 40 & 0.820 & 7.65 & 0.030 & 0.155 & 0.665 & 0.238 & 0.126 & 18.90 \\
5. & 2.8 & 50 & 1.025 & 10.20 & 0.040 & 0.206 & 0.819 & 0.292 & 0.137 & 20.09 \\
6. & 2.8 & 70 & 1.435 & 18.45 & 0.073 & 0.373 & 1.062 & 0.379 & 0.193 & 25.99 \\
7. & 2.8 & 80 & 1.640 & 25.70 & 0.102 & 0.520 & 1.120 & 0.400 & 0.255 & 31.70 \\
8. & 2.8 & 100 & 2.05 & 36.95 & 0.146 & 0.745 & 1.305 & 0.466 & 0.313 & 36.34 \\
\hline \hline
\end{tabular}

$\mathrm{m}=$ weight of activated carbon $(\mathrm{g}) ; \alpha_{\mathrm{o}}=$ amount of carboxylic acid added to the bottle $(\mathrm{g}) ; \mathrm{C}_{\mathrm{e}}=$ concentration of carboxylic acid left in solution at equilibrium (mole/L); $\alpha_{\mathrm{e}}=$ amount of carboxylic acid left in solution at equilibrium in the bottle $(\mathrm{g})$; $\mathrm{X}=$ amount of carboxylic acid adsorbed $(\mathrm{g}) ; \mathrm{Q}_{\mathrm{e}}=$ adsorption capacity of acids $(\mathrm{mg} / \mathrm{g})$.

Table 5. Adsorption of butyric acid on activated carbon

\begin{tabular}{lllllllllll}
\hline \hline $\begin{array}{l}\text { S. } \\
\text { no. }\end{array}$ & $\begin{array}{l}\mathrm{m} \\
(\mathrm{g})\end{array}$ & $\begin{array}{l}\text { Dilution } \\
(\%)\end{array}$ & $\begin{array}{l}\alpha_{\mathrm{o}} \\
(\mathrm{g})\end{array}$ & $\begin{array}{l}\mathrm{NaOH} \\
(\mathrm{mL})\end{array}$ & $\begin{array}{l}\mathrm{C}_{\mathrm{e}} \\
(\mathrm{mole} / \mathrm{L})\end{array}$ & $\begin{array}{l}\alpha_{\mathrm{e}} \\
(\mathrm{g})\end{array}$ & $\begin{array}{l}\mathrm{X}=\alpha_{\mathrm{o}}-\alpha_{\mathrm{e}} \\
(\mathrm{g})\end{array}$ & $\begin{array}{l}\mathrm{X} / \mathrm{m} \\
(\mathrm{g})\end{array}$ & $\begin{array}{l}\mathrm{C}_{\mathrm{eq}} \\
(\mathrm{g})\end{array}$ & $\begin{array}{l}\mathrm{Q}_{\mathrm{e}} \\
\mathrm{mg} / \mathrm{g}\end{array}$ \\
\hline 1. & 2.8 & 4 & 0.07 & 0.05 & 0.0002 & 0.002 & 0.068 & 0.024 & 0.0082 & 2.85 \\
2. & 2.8 & 16 & 0.280 & 3.05 & 0.0121 & 0.0532 & 0.2268 & 0.081 & 0.1493 & 19.28 \\
3. & 2.8 & 24 & 0.420 & 5.75 & 0.0228 & 0.1003 & 0.3197 & 0.114 & 0.200 & 24.04 \\
4. & 2.8 & 40 & 0.700 & 12.85 & 0.0509 & 0.224 & 0.476 & 0.170 & 0.2994 & 32.00 \\
5. & 2.8 & 50 & 8.75 & 16.90 & 0.0670 & 0.295 & 0.580 & 0.207 & 0.3236 & 93.37 \\
6. & 2.8 & 70 & 12.25 & 29.15 & 0.1155 & 0.508 & 0.717 & 0.256 & 0.4512 & 94.14 \\
7. & 2.8 & 80 & 14.00 & 31.25 & 0.1397 & 0.615 & 0.785 & 0.280 & 0.4989 & 94.39 \\
8. & 2.8 & 100 & 17.5 & 50.35 & 0.1996 & 0.878 & 0.872 & 0.311 & 0.6418 & 95.01 \\
\hline \hline
\end{tabular}

$\mathrm{m}=$ weight of activated carbon $(\mathrm{g}) ; \alpha_{\mathrm{o}}=$ amount of carboxylic acid added to the bottle $(\mathrm{g}) ; \mathrm{C}_{\mathrm{e}}=$ concentration of carboxylic acid left in solution at equilibrium (mole/L); $\alpha_{\mathrm{e}}=$ amount of carboxylic acid left in solution at equilibrium in the bottle (g); $\mathrm{X}=$ amount of carboxylic acid adsorbed $(\mathrm{g}) ; \mathrm{Q}_{\mathrm{e}}=$ adsorption capacity of acids $(\mathrm{mg} / \mathrm{g})$.

as shown in Fig. 4. The value of $\mathrm{X} / \mathrm{m}$ ranges from 0.024 to 0.311 and $\mathrm{C}_{\mathrm{eq}}$ values from 0.008 to 0.64 as shown in Table 5 .

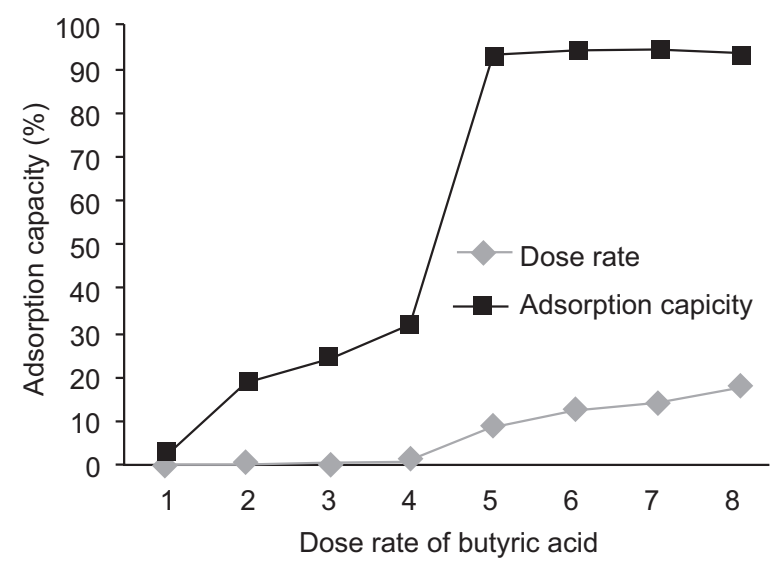

Fig. 4. Effect of dose rate on adsorption capacity of butyric acid.

\section{Conclusion}

Percent removal of BA, PA, VA and BUA increases with the increase in adsorbent dose. All acids used in experiments showed better result at acidic $\mathrm{pH}$. Optimum adsorption capacities were found to $91.30 \%, 65.28 \%$, $41.47 \%$ and $93.37 \%$ at dosing rate of $2.60 \mathrm{~g}, 1.47 \mathrm{~g}$, $0.69 \mathrm{~g}$ and $8.75 \mathrm{~g}$ for BA, PA, VA, BUA, respectively. At different dose rates with same contact time the adsorption capacity increases with an increase of concentration. However, amount adsorbed per amount of adsorbent increases with an increase of dosing rate of each acid.

\section{References}

Abe, M., Kawashima, K., Kozawa, K., Sakai, H., Kaneko, K. 2000. Amination of activated carbon and adsorption characteristics of its aminated surface. Langmuir, 16: 5059-5063. 
Ania, C.O., Parra, J.B., Pis, J.J. 2002. Influence of oxygen-containing functional groups on active carbon adsorption of selected organic compounds. Fuel Processing Technology, 79: 265-271.

Ayranci, E., Duman, O. 2006. Adsorption of aromatic organic acids onto high area activated carbon cloth in relation to wastewater purification. Journal of Hazardous Materials, 136: 542-552.

Baudu, M., Le Cloirec, P., Martin, G. 1991. Pollutant adsorption onto activated carbon membranes. Water Science and Technology, 23: 1659-1666.

Bertleff, W., Roeper, M., Sava, X. 2005. Carbonylation. In: Ullmann's Encyclopedia of Industrial Chemistry, Weinheim: Wiley-VCH, doi:10.1002/14356007. a05_217

Dina, D.J.D., Ntleche, A.R., Ndi, J.N., Ketcha, M.J. 2012. Adsorption of acetic acid onto activated carbon obtained from maize cobs by chemical activation with zinc chloride $\left(\mathrm{ZnCl}_{2}\right)$. Research Journal of Chemical Sciences, 2: 42-49.

Dong, C., Mei, Y., Chen, L. 2006. Simultaneous determination of sorbic and benzoic acids in food dressing by headspace solid-phase microextraction and gas chromatography. Journal of Chromatography A, 1117: 109-114.

Haghseresht, F., Nouri, S., Lu, G.Q. 2002. Effects of the solute ionization on the adsorption of aromatic compounds from dilute aqueous solutions by activated carbon. Langmuir, 18: 1574-1579.

Kipling, J.I. 1965. Adsorption from Solutions of NonElectrolytes. Academic Press, New York, USA.

Rodriguez-Reinoso, F., Molina-Sabio, M. 1998. Textural and chemical characterization of microporous carbons. Advances in Colloid and Interface Science, 77: 271-294.

Xin, X., Si, W., Yao, Z., Feng, R., Du, B., Yan, L., Wei, Q. 2011. Adsorption of benzoic acid from aqueous solution by three kinds of modified bentonites. Journal of Colloid and Interface Science, 359: 499504.

Yan, L.G., Wang, J., Yu, H.Q., Wei, Q., Du, B., Shan, X.Q. 2007. Adsorption of benzoic acid by CTAB exchanged montmorillonite. Applied Clay Science, 37: 226-230. 